\title{
Whose Paradise? Encounter, Exchange, and Exploitation
}

\section{Kalissa Alexeyeff and Siobhan McDonnell}

\begin{abstract}
$\mathrm{T}_{\mathrm{h}}$ he opening scenes of Disney's 2016 animated feature film Moana take the viewer on a tour around the tropical island of Motunui. First we see the glittering ocean, white sand, and palm trees. Then we experience life in the village, where coconuts fall from trees, grass is soft and lush, flowers and foliage are plentiful, fish spill out of woven baskets, and bananas and taro grow large. The inhabitants of the village are industrious but not overworked. They are generous; they "share everything they make." They are happy seeming, dance throughout the day, joke as they weave baskets, and appear content pounding, drying, and decorating tapa. The island is bountiful, and the people living there are beautiful, healthy, and strong. The film's message is clear: This is paradise. Every cliché pertaining to Pacific paradise is employed in these early scenes to frame Moana's subsequent narrative. But the people of this bountiful island harbor a dark secret: the loss of their will to navigate the powerful ocean-going canoes of their past. The utopic appearance is counterposed with the theme of paradise lost: the heroine must contest the withering darkness that challenges the very existence of this island and her people; she must restore the heart of Te Viti so as to repossess paradise and re-green the world.

As many readers of this journal will be aware, Moana's representation of the Pacific and its environments, communities, and histories has generated intense debate among Pacific Islanders. In this debate, a range of diverse and divergent opinions have been presented. For example, students at Auckland University created a short documentary of student interviews outlining issues of appropriation and theft and corruption of cultural traditions evident in Moana (Iron Lion 20I6). When teaching a course on culture and development at the National University of Samoa in 2016 , Kalissa Alexeyeff showed this film to a group of graduate stu-
\end{abstract}

The Contemporary Pacific, Volume 30, Number 2, 269-295

(C) 2018 by University of Hawai'i Press 
dents with the intention of engaging with these debates on cultural theft. The Samoan students, however, were nonplussed; from their perspective, Moana was to be celebrated as a rare moment of cultural pride on a global stage-an opinion that has been echoed in many other communities, be they villages, rural towns, or cities. This experience suggests that enduring debates about Moana are too easily_and erroneously_characterized as between those who live within the Pacific diaspora (and therefore within the racist logics of settler colonial societies) and those who reside in home islands. Such homelands/diaspora dualism relies on nation-state cartography that emphasizes insularity and occludes the movement of people and ideas between and within Oceania.

We begin with this brief discussion of Moana to highlight the major themes of this collection. The first theme is how concepts of paradise are mobilized to animate processes of neocolonization, which are evident, for example, in the appropriation of Indigenous knowledge, in Pacific tourism, and in Western popular culture. Vicente Diaz labeled Moana as another instance of the long history of Western "Polyface" that serves to "whitewash colonialism and normalize its attendant violence and devastation of land, sea and tradition" (Diaz 2016). He strongly argued that whitewashing is done via the trope of paradise (and Polynesian paradise in particular), a fictive construct created from European "fantasies and desires." We agree with Diaz's conclusion that Pacific paradise is an imaginary that enacts the material dispossession of colonialism. As he suggested, "The longing for such an imagined paradise is called colonial nostalgia; in this case, it is a desire to retrieve and possess what European and American colonialism destroyed" (see also T Teaiwa 2016; Ngata 20I6). Expanding on Diaz, this collection explores in part how the cultivation of foreign desire continues to have potent, tangible impacts on Pacific peoples and places, which is described in this special issue as possession.

This collection also aims to interrogate another aspect of the paradise paradox that Moana has brought to the forefront by asking the following questions: How are we to understand and do justice to the perspectives of Pacific Islanders (both those who are familiar with the above critiques and those who are not) who expressed pride, enjoyment, and excitement about this film? And what about those who participated purposively in its making because they saw it as a way to intervene in the process of representation? We suggest that these viewpoints cannot be dismissed as a form of seduction, wishful thinking, or neocolonial false consciousness. Thus, 
the second theme of this special issue is the way that concepts of paradise are mobilized and repossessed by Pacific peoples.

Besides using possession to indicate ideological and material expropriation by outsiders, we are equally concerned in this collection with acts of repossession. All the essays explore how the paradise trope is deployed by Pacific peoples in contexts that range from tourist performances to land claims, religious discourse, popular culture, and artwork. In each context, paradise works to deconstruct colonial forms of possession and assert Indigenous agency and worldviews. This dialectic between possessing and repossessing paradise propels our inquiry. We aim to keep the interplay between appropriation and reappropriation at the forefront of our analyses in order to highlight the array of perspectives and strategic interventions that occur across complex neocolonial settings.

Mārata Tamaira and Dionne Fonoti extend our opening analysis through a detailed exploration that combines a textual analysis of Moana with perspectives on the production and consumption of the film. Fonoti's viewpoint from her involvement with the Oceanic Story Trust in consulting on the portrayal of Pacific cultural traditions in the film is put in dialogue with those of various critics and champions of the production process. The authors argue that the dynamics of cultural appropriation and engagement are complex and sticky (see also Tamaira 20I6). Their essay discusses how strategic, collaborative engagements between Indigenous communities and global corporate enterprises can proceed in ways that may not further exploit Pacific people and places. While acknowledging asymmetries of power, they also consider the contradictions and tensions that exist in the terrain of global capitalism. These fault lines open up spaces for critical interventions that destabilize hegemonic processes, and, as a result, may potentially benefit Indigenous communities.

Like the representation of paradise in Moana, Pacific paradise is analyzed throughout this issue as multidimensional — both as a construct of exploitative Western imaginaries and as a trope that is infused with Pacific histories and epistemologies that speak to Pacific Islanders in meaningful and deeply affective ways. Kalissa Alexeyeff analyzed this double valence when writing about how Cook Islanders living in New Zealand hang generic tourism posters in their homes to evoke and create a sense of island paradise (Alexeyeff 20I6). "Re-purposing paradise," as she depicted it, shows how paradisiacal objects can articulate dispossession while serving as agentive acts of repossession, evoking Indigenous ways of being and knowing in more meaningful terms. 
This collection arose from thinking about how Pacific Islanders utilize the trope of paradise to describe their lives and the places they call home. Like the many studies that precede this, our work demonstrates how paradise has come to define the Pacific through certain kinds of generic, infinitely reoccurring, and highly substitutable images: beautiful beaches, verdant foliage, and exotic peoples and customs. We show how these images enable possession (from early exploration, through colonial settlement, and including contemporary tourism) and how this is twinned with the dispossession of land, Indigenous peoples, and their epistemologies. What distinguishes this collection from most previous literature is that we combine analyses of contemporary possession with repossession in our exploration of the ways in which Indigenous people reimagine or repurpose paradise for their own needs and desires. Several contributors in this special issue focus on how Indigenous people and groups utilize ideas of paradise as a vehicle to critique, contest, and intervene in foreign appropriation and exploitation (see articles by Tamaira with Fonoti, Alexeyeff and Kihara, and Jolly). These Indigenous framings show concepts of paradise being reanimated to explore and debate contemporary issues, including, for example, the relative power of divine and human control over the devastating impacts of climate change (see essay by Cox and others). Other articles in this issue explore the contemporary economic forces associated with commodifying the Pacific as paradise, rendering the Pacific available for consumption by foreigners, whether as real estate developers, tourists, or popular cultural audiences (see essays by Currie and McDonnell). These processes of commodification, while taking place in the context of global capitalism, often involve local Indigenous actors who adopt foreign desires strategically to meet their own needs.

Our engagement with encounters between Pacific and non-Pacific economic, political, and ideological forces and agendas focuses on the dynamic configurations of possession and repossession in the complex space of negotiation between Indigenous representations of place, foreign investments in paradise, and the encroachment of global capitalism. Through these countervailing forces and complex crosscurrents, Pacific paradise emerges as a potent if long-contested trope that materially generates a whole range of Western and Pacific realities, desires, and aspirations. To capture these complex formations, this special issue thus moves beyond the idea of Pacific places as "paradise" as merely artificial, superficial, or illusory. Throughout the articles in this collection, important questions about global power and structural inequality remain: Whose 
interests does paradise serve? How is the discourse of paradise mobilized, commodified, and purchased? And whose "paradise" is reflected in these ideas and images?

\section{ENCOUnTERs With Paradise: \\ Global and Pacific Literatures}

While numerous genealogies of "paradise" might be identified throughout world cultures, the paradise concept as often articulated in Western film, literature, and scholarship originated in Indian, Persian, and Arab notions of an enclosed garden. The original Zoroastrian word pairidaeza merged with Judeo-Christian concepts to produce meanings that combined ideas of terrestrial delight with the Garden of Eden as a site of original sin (Grove 1995, 23; Deckard 2010, 2). Paradise also came to signify a future heavenly state paired with its opposite-an afterlife of infernal punishment. This temporal and spatial malleability is further evidenced in the way paradise reflects and refracts key contradictions and obsessions of particular historical moments (Strachan 2002; Deckard 2010). Writing on "green imperialism," Richard Grove illustrated how fifteenthcentury European colonization of the Americas witnessed an expansion of an "Earthly paradise" ideology to motivate, as well as to legitimate, material exploitation of resources and peoples in other parts of the world (Grove I995). Paradise may exist elsewhere, but it could be found, conquered, and possessed. The Christian narrative of fall and redemption told through paradise tropes also crucially helped to curate missionary evangelism in the Pacific and elsewhere through images of conversion as a movement from darkness to light. The story of capitalism is similarly told through oppositional tropes of paradise and anti-paradise, or paradise lost (Deckard 2010,I-4; Sahlins 2008). Depending on the historical moment and ideological position deployed, colonized lands and peoples came variously to stand for "our" Edenic past, which has been ravaged by civilization through to its opposite-a depraved wasteland that requires spiritual work alongside productive enterprise.

Discovering Sharae Deckard's 2010 book Paradise Discourse, Imperialism, and Globalization: Exploiting Eden propelled us to consider connections between paradise, colonialism, and global capitalism. Paradise Discourse reads across a range of postcolonial literature that engages with the concept of paradise, situating the works within political and economic processes of capitalism's long modernity. In that work, Deckard argued 
that paradise enables ideological fantasies of bountiful fecund landscapes and labor-free profit, thereby sustaining myths of wealth literally falling from trees. The material conditions of land alienation and forced labor that actually underwrite the global economy are thoroughly depoliticized in these romantic visions. From early European exploration, to colonial invasion and settlement, to the continuing economic and leisure imperialism of former colonies through global capital and tourism, paradise discourse has been repeatedly deployed to mask capitalist modes of wealth extraction, exploitation of human and environmental resources, and capital accumulation.

Colonial expeditions imagined paradise as a kind of New World treasure trove, ripe for exploitation. Colonial voyagers were motivated by fantasies of finding a lost city of gold-the mythical place of "El Dorado"-that began with Columbus's attempt to find the island of Samoet (Deckard 20I0, 8; Grove I995, 32-33). In the Pacific, Spanish Conquistador Hernán Cortés dispatched two vessels in I 537 to explore the ocean between South America and the Moluccas in an attempt to find islands laden with gold (Amherst and others I967, iii). In a subsequent Spanish expedition, Alvaro de Mendaña sailed to what was later termed "the Solomon Islands," referencing islands containing the fabled gold of King Solomon. In this act of Spanish naming, the ideas of New World gold became transposed onto a physical place, creating literal treasure islands (see Francis Bacon's incomplete utopian novel, The New Atlantis, published by his executor in I627, as a further example).

Some two hundred years after Mendaña, the French explorer LouisAntoine de Bougainville sailed to Tahiti in I768. Bougainville's report of his voyages to Tahiti describes an Edenic locale where local women readily entered into sexual liaisons with sailors (Bougainville I772; Tcherkézoff 2009; Jolly, Tcherkézoff, and Tyron 2009). Here, the alluring nature of the newly "discovered" landscape is entwined with the libidinous longings of the French sailors and explorers for Tahitian women. In his account of his voyages, Bougainville repeatedly references an Edenic idyll, where people live in harmony amid nature's bounty, provoking something of a "Polynesian vogue" in Europe (Kahn 2003, 3 IO). The voyages of Bougainville, along with those of George Anson and James Cook, created in the European consciousness the idea of tropical islands as practical locations of utopia, defined in both social and physical terms by Renaissance and Enlightenment scholars (Dening 1992; Salmond 2003; Thomas 2003, 20I0; Jolly, Tcherkézoff, and Tyron 2009; Tcherkézoff 2004, 2009). 
Through these processes of foreign encounter, "the island" became for Western Europeans a visceral cultural metaphor and was subsequently deployed in art and literature ranging from Shakespeare's The Tempest to the accounts of Sir Francis Drake and the works of John Donne and John Milton (Grove I995, 33).

Colonial narratives of "discovery" in the Pacific were punctuated by images and texts produced by the artists, scientists, and explorers who participated in these expeditions. The earliest scholarly work to analyze these was Bernard Smith's European Vision and the South Pacific (I985 [1960]). Interestingly, Smith did not list "paradise" in the index of this work, using instead "Arcadia (Eden)." Nevertheless, his analysis of early voyages of "discovery" demonstrated the traction of paradise discourse. On Cook's first voyage (I768-I77I), Tahiti was evoked as a "deistic paradise of innocence and natural virtue" (Smith I985, 44). Cook himself romantically described an abundant Arcadia: "Benevolent nature hath not only supply'd them with neccessarys but with abundance of superfluities" (quoted in Smith I985, 44). While Cook and British naturalist Joseph Banks may have sung the praises of "natural" luxury inhabited by contented (if somewhat indolent) noble savages, subsequent voyagers increasingly came to construct paradisiacal bounty as an index of moral degeneration and decay. Alongside economic and political agendas in the region, evangelical interests promulgated visions of deceitful, treacherous, and "untutored offspring of fallen nature" (Smith I98 5, I47).

Following Smith's seminal work, Pacific scholarship has engaged abundantly with colonial systems of representation. European exploration, as well as colonial and missionary expeditions, has been subjected to thorough interrogation (Grimshaw I989; Jolly I992, 2009; Calder, Lamb, and Orr 1999; Thomas 2003; Tcherkézoff 2004, 2009; O’Brien 2006). Analyses of accompanying artifacts, reports, diaries, drawings, paintings, and specimens (human, animal, and botanic) and their role in advancing European imperialism all demonstrate how ideas of paradise have animated foreign imaginings of an "exotic" Pacific across centuries and across a range of geographical locations (Thomas 2003; Newell 2006).

Scholarly attention has also focused on the art and literature of the early twentieth century. Gauguin, was seeking refuge from civilization in the "simpler," more natural, and less repressed Pacific paradise, though he was sorely disappointed in Tahiti and thus moved to the Marquesas (Eisenman I997; Jolly I997a; T Teaiwa I999). Scholars have also paid attention to the ways in which the Pacific has been portrayed in cinema, creating a 
romantic backdrop for foreign yearnings (Nelson I992; O’Dwyer I995; Dening I996; Jolly I997b; Mawyer 1998; Landman 2006; Landman and Ballard 20I0; Fresno-Calleja 2013). Concurrently, the trope of Pacific paradise has also been subjected to sustained critique in the context of Pacific tourism. Tourism, as a form of hedonistic imperialism, replicates colonial processes of conquest, commodification, and exploitation (Trask I993; T Teaiwa I994; Hall I998; Desmond 1999; Alexeyeff 2008; Kahn 20II; Taylor 20I6; MacCarthy 20I6). Pacific tourism imagery involves commodified representations of Edenic lifestyles, natural beauty, and bounty, which are all available to tourists for the price of an air ticket and the cost of resort accommodation.

In the context of this existing scholarship, is there anything more to be said about the representation of Pacific as paradise? We believe there is. By presenting paradise discourse as a dialectic of dispossession and repossession, we engage a body of scholarship that considers multidirectional exchange and mutually transformative encounters between Pacific and non-Pacific peoples. This includes not only colonial exchange (Salmond I991, I998; Thomas I991, 2010; Jolly, Tcherkézoff, and Tyron 2009; Hermann 20II; Matsuda 20I2) but also contemporary understandings of race, gender, and sexual identity (Wallace 2003; Besnier and Alexeyeff 20I4; Jolly 20I6), and the co-constitution of people and property relations (Strathern I988; LiPuma I998; Sykes 2007; McDonnell 2016) and industries, such as tourism (Taylor 200I; Trask I993; Desmond I999; Kahn 2003, 20I I; Alexeyeff and Taylor 2016).

Engaging with paradise entails exploring the movement of people, ideas, and images both of and within the contemporary Pacific. Deckard's work provides us with a framework to think about paradise narratives as part of a global discourse attached to the economic and political logics of capitalism. We believe that this wider lens is significant for a reconsideration of Pacific paradise, enabling us to apprehend new formations of capitalist economics that not only penetrate all corners of the globe but also increasingly govern our bodies, ideas, and practices. Deckard's direct and uncompromising link between paradise and capitalist processes, land alienation and the associated dispossession of people, exploitation of labor, and commodification of cultures speaks directly to dynamics at work in the contemporary Pacific. The last thirty years have witnessed both the stark expansion and, simultaneously, the uneven spread of capitalist markets and consumption. The globalization of trade, supply chains, large-scale migration, and the hegemony of neoliberal forms of economic develop- 
ment and governance have seen understandings of property, ownership, and personhood transforming dramatically in response.

Technological advances mean that communication networks are now transnational; the Internet and social media connect users to new and emerging forms of sociality and consumption. These developments are paradoxical in that they have the potential to create new forms of both connection and fragmentation, generating emerging possibilities while also deepening systems of inequality. In this way, they represent the changing contours of "compressed globalization," creating new kinds of local engagement and political activism (Hviding 2004). The possibilities for critique and resistance from "outside" or on the "margins" of capitalism require creative political engagements from within, albeit from locations where the contradictions of global capital are most evident, as in Pacific islands experiencing the impacts of climate change. For many Pacific intellectuals and artists, paradise occupies a highly contested place and provides fertile ground for vigorous debate about key social issues of the here and now.

\section{Your Paradise: Possessing/Repossessing}

A quick search of the terms "paradise" and "Pacific" on the Internet reveals carefully curated representations of the Pacific that are deeply encoded in foreign imaginaries. Amid these sites appears one for an electronic music festival held annually in Fiji and titled "Your Paradise." Images appear in quick succession: a white sand beach fringed by palm trees, then images of young white tourists, often scantily clad, engaged in play-jumping off boats, riding bicycles-before the camera pans across blue waters to scenes of revelry on what appear to be isolated beaches. As the promotional advertisement finishes, the words "Your Paradise" appear on the screen, framing a white couple standing in blue waters, on white sand, holding a printed sign between them that reads "Welcome to Your Paradise." In this instance, the trope of "paradise" requires Fiji to become a backdrop for romance between white heterosexual couples and a location for a holiday that is also a dance party, rather than a place belonging to the local inhabitants. The people who "belong" in this carefully curated paradise are other foreign revelers who are being enticed to come and join in the fun.

"Your Paradise" is just one example of the endless stream of contemporary tourism material in which the Pacific is represented as empty sand beaches framed by coconut palms and "crystal" blue waters. In these 
images, Pacific landscapes serve as a playground for white people (and increasingly today for East Asian people) engaged in spectacles of leisure. In doing so, they disguise the deep global inequalities that allow Westerners to fly and play in landscapes in ways that are often unavailable to cash-poor local inhabitants. These economic and social discrepancies are partially obscured by the manufacture and marketing of Pacific places as paradise. Pacific islands have a resonant currency as Edenic places of natural beauty, far removed from the stresses of late capitalism.

While highly gendered and romantic images of the Pacific as "paradise" are adopted by tourism operators and adapted by other local investments, hegemonic images of sun, sex, and sand have also been subject to sustained critiques that reveal their highly racist and sexist configurations (Trask I993; T Teaiwa I994; Jolly I997a; Desmond I999; O'Brien 2006). Such visions can clothe the complex political contours of military engagement, real estate dealings, and tourist encounters in Pacific places. Here, the material possession of the landscape by foreigners, or foreign interests, may be fleeting or may markedly reshape the landscape, potentially resulting in the dispossession of Indigenous peoples.

In this special issue, we consider how the act of possession begins with the act of imaging (Said I993; Appadurai 1986). Possession here is configured not only with respect to control over the landscape-such as the creation of gated resorts for tourists—but also of prior possession through the visual depiction of Pacific landscapes through reality television, tourism, and real estate campaigns. In her article, Siobhan McDonnell shows how visual representations actively construct places in the mind of the viewer as a first step in enabling the neocolonial domination of Pacific landscapes. The reality television series Survivor, Pacific tourism, and real estate advertisements all carefully manufacture an aesthetic based on the terra nullius trope, or that of a landscape empty of local people, awaiting possession. Tourism and real estate advertisements include images of landscapes either unpeopled or peopled by a single white person. These representations function as a visual reduction of the landscape. McDonnell illustrates how Pacific real estate advertisements render the landscape flat and function to commodify paradise as "property." Foreign dreams are transposed onto Pacific landscapes in ways that demonstrate little consciousness of actual local circumstances. In Vanuatu, idyllic real estate images conceal the tensions that lie beneath the superficial touristic encounter, and these underlying tensions are then aggravated by the purchase of customary land. 
In discussing possession, we are interested in how Western concepts of property can be contrasted with Pacific understandings of access and use rights-rights to land, to marine resources, and to knowledge. Across Oceania, deep attachment to place is often expressed in phrases such as "my land, my life" (McDonnell 20I6; Huffer 2008; Larmour 20I3). Concrete and material practices of attachment to place are articulated, for example, through customary systems of land management that often create a complex tapestry of access and use rights to resources (Ballard 20I3; Filer, McDonnell, and Allen 20I7). By contrast, both production and consumption in the global economy require property and capital to be owned and accumulated by possessive individuals (or groups thereof, like "landowners"). This concept of property conceals the way use and access rights configure relations between people by representing them as rights that possessive individuals can exercise independently. The forced and often violent removal of people from place and the expropriation of land for commerce are systematic acts of dispossession in colonial and neocolonial settings.

In his writings on commodity fetishism, Karl Marx described the process by which the social relations between people in a capitalist economy become displaced by the value attributed to commodities (Marx I990 [I867], 3). As Martha Kaplan has suggested, mass tourism represents the culmination of Pacific paradise as "transacted object" (Kaplan 20II, 22I). That "Pacific" is synonymous with "paradise" has enabled the production of commodities that exist in worlds far beyond Pacific places. Imagined possibilities are no longer related to travel encounters; they can be used to sell water, perfume, and other commodities as well. As both Kaplan (20II) and John Connell (2006) have shown, FIJI Water has been marketed as the "Taste of Paradise," a product of a virgin, pristine ecosystem. Kaplan termed this a "Pacific romance" that involves consumption and appropriation of the exotic by foreign markets, which thereby functions, we argue, as an example of commodity fetishism that removes any understanding of the social and labor relations from the production of FIJI Water. While we appreciate Kaplan's analysis of Indigenous engagement with foreign iterations of paradise, we further suggest that an autochthonous "romance," built on generations of habitation and ownership of land, would also contribute to local understandings of and attachments to place. Indeed, untangling the local and global (colonial, neocolonial) utilizations of paradise, while rhetorically possible, is harder to accomplish in actuality. In the spaces of compressed globalization, Indigenous actors are 
also instrumentally involved in the commodification of Pacific paradise and in the expropriation of other Indigenous people from their land.

Here, we are proposing that paradise is not an inert commodity but rather has its own social life; paradise is an object that circulates through particular social and cultural settings. This genealogical approach to commodities, as described by Arjun Appadurai (I986), Sidney Mintz (I985), Robert Foster (2008), and Katerina Teaiwa (20I4), among many others, provides a related avenue for us to comprehend the multidirectional traffic that shapes, engages, and competes in the meaning making of the commodity in circulation. In Coca-Globalization (2008), Robert Foster traced the movement of the soft drink Coca-Cola (or Coke) from New York to New Guinea. Through this journey, he demonstrated how commodities are mutable, how meanings are transformed, and how consumers are able to appropriate objects for a variety of ends and creative adaptations. They can, to use his terminology, be embedded or dis-embedded from particular social relations and re-embedded in other social settings. Indigenous agents operate within structural inequalities that serve to shape meaning making, possession, and repossession.

In this way, and across a range of cultural settings, paradise is variously gifted, stolen, traded, and sold. Identifying key social and political exchanges and varying circulations of paradise tropes reveals not only the dynamics of possession and dispossession but also the politicized processes of repossession that concerns many of the authors in this collection. To this point, Sara Currie's article provides an example of how paradise is repurposed in the recently independent nation of Timor-Leste. Currie provides fascinating insights into how tourist advertising campaigns are developed, requiring us to produce more nuanced and perhaps less cynical understandings about tourism marketing. Drawing on her graduate research and her professional role in developing this campaign, Currie considers the ethical and moral implications of "destination marketing." Somewhat idealistically, she had entered the campaign project hoping to avoid the commodification of paradise that the hegemonic "sun, sea, and sand" model (elsewhere referred to as sun, sex, and sand) promotes so clearly. In her research and campaign, she utilized the knowledge of Timorese tourism stakeholders in an attempt to avoid these pitfalls. Ironically, many of these stakeholders acknowledged and expressed preference for orthodox representations of paradise for both pragmatic commercial and affective reasons. In collaborative development, these affective ties to place are foregrounded in the campaign in ways that, while not disman- 
tling the paradise trope, serve to stamp Indigenous possession onto the landscape, thereby shifting, to a degree, neocolonial structures of power.

The complex tensions between Indigenous Kanaka Maoli sovereignties and imperial militarized expansion are explored in Margaret Jolly's lyrical essay in this collection. Hawai'i has long been seen and contemplated as a landscape that conjoins tourism and militarism. In Bananas, Beaches and Bases (1989), Cynthia Enloe drew attention to the cohabitation of military and tourist industries, most notably in sex tourism, but also in terms of infrastructure-flights, access to services, and strategic economic interests (see also T Teaiwa I994; Gonzalez 2010). Here, Jolly draws on her experiences with an Australian National University field school in Hawai'i to offer three vignettes that describe how paradisiacal notions continue to frame acts of possession, dispossession, and repossession there. Jolly describes how Disney's Aulani Resort creates an artificial, carefully curated "paradise" in the form of a watery wonderland (see also Tamaira 20I6). A Kanaka Maoli tour guide takes Jolly and her students around the resort, drawing on Hawaiian concepts of ahupua'a land divisions to describe the flow of water through the site and to highlight how these cultural motifs are challenged by the pragmatic reality that the resort draws vast water supplies from elsewhere in O'ahu. The flow and diversion of water toward tourist hotels and infrastructure serves as an important physical reminder of the ways in which these sites of artificial paradise can remake physical landscapes. But paradise discourse can also be used in repossession, and Jolly shows how the combined forces of Christianity and commodity economics, as well as visions of ancient Hawaiian life, become political tools for Kānaka Maoli to "oppose imperial occupation and proclaim their sovereignty in their homeland."

While we have acknowledged the potency of "paradise" for the West, we have also suggested that it would be a mistake to assume that local engagements amount to straightforward dismissals of "paradise." This assumption is implicit in analyses of paradise as an illusory marketing ploy that locals can see through and beyond. In contrast, we argue that "paradise" is both an imaginary that frames foreign engagement with the Pacific as well as a complex and often contradictory landscape utilized in Indigenous articulations of home and belonging. It should not come as a surprise that European imaginaries of paradise are also deeply embedded in the lives and landscapes of postcolonial peoples. Paradise then, is not simply a trope that works at the behest of capitalism and those whose interests it serves. For instance, the postcolonial writers that Deckard 
explores in her book reclaim the trope of paradise to critique Euro-American colonial legacies across economic, political, and ideological spheres. Sometimes this is done through overt critique and at other times paradise is deployed as an iconic, ironic motif to expose structural inequalities. Similarly, in Pacific communities today there is a wide range of critical appropriations of the concept of paradise.

In this vein, John Cox, Glen Finau, Romitesh Kant, Jope Tarai, and Jason Titifanue offer a complex argument about the way that Christian narratives are evoked in Fiji in times of disaster and the implications that this has for discussions of climate change in Fiji and across the Pacific region. In Fiji, a number of Christian groups have seen Tropical Cyclone Winston as a sign of God's wrath visited on a sinful people. These authors note that Fijian concepts of vanua (simultaneously referring to people and land) are evoked as signaling an Indigenous "Golden Age," rendering contemporary populations of iTaukei as a "chosen people inhabiting a promised land" (see also Tomlinson 2002). In the wake of Cyclone Winston, Christian evangelists adopted these narratives to claim that the disaster was an act of divine judgment on people who had fallen from grace by failing to respect the covenant between God and Fijians. These moral narratives have political intent in that they reapportion blame away from carbon-emitting countries, such as Australia and the United States, and onto Fijians themselves.

Repossession occurs most clearly in works of Pacific artists and writers who thoroughly dismantle stereotypical images of paradise (see Taouma 2004; Tamaira 20I0). For example, much of Samoan artist Yuki Kihara's work is a commentary on colonial possession and Indigenous dispossession. Her photographic exhibition Fa'afafine: In the Manner of Women (2005) mimics the work of colonial portraiture of near-naked "native women." It is also an act of repossession. Kihara's "dusky maiden" is fierce as she stares at the camera with knowing insouciance; her direct gaze, as bell hooks in Black Looks: Race and Representation argued (2015 [1992], xii), "invites interrogation, contestation, daring us to look and see differently." Furthermore, the "dusky maiden" is also not all that she seems, as across the triptych she is undressed to reveal a penis as well as breasts, in a manner that confounds and unsettles colonial constructions of sexuality and desire.

Kalissa Alexeyeff and Yuki Kihara take up these dynamics and processes of neocolonial possession in dialogue with Kihara's 2016 photographic and video installation piece Der Papālagi (The White Man). The 
work takes as its starting point Erich Scheurmann's Der Papālagi, which was published in 1920 as a (fictitious) Samoan chief's commentary on the ills of Western "civilisation" in contrast to Polynesian paradise. Kihara inverted this masquerade by placing two German expatriates in chiefly regalia in urban spaces across Apia. In doing so, the work asks questions about the line between cultural appropriation and appreciation and the power relations embodied in these exchanges. In analyzing Kihara's work and the responses it generated, Alexeyeff and Kihara pay attention to specificities of place-based articulations of race, exploring how these cross-dressing moments serve to unravel foundational Euro-American markers of racial identity. They demonstrate how racialized structures are sources of hegemonic power but are also highly manufactured in specific socio-spatial relations in particular places.

\section{Conclusion: Beyond Paradise Lost}

The narrative arc in the film Moana depicts the encroachment on paradise of a veil of darkness that represents the destruction of the natural world. The lead character, Moana, must search for and restore the heart of Te Fiti (the goddess of earthly regeneration) so as to save her world from annihilation. One reading of this story is that the darkness provides a visual metaphor for the looming specter of climate change in the Pacific. The immense impacts associated with climate change in the Pacific are materially transforming people's lives-affecting where they can live, how often they can plant and harvest food crops, their capacity to fish, and how often they are subject to "natural" disasters. These impacts speak to the deep global inequalities between carbon-emitting countries and the people of Oceania who produce virtually no carbon-the Pacific Ocean being one of the world's great carbon sinks. We do not wish to discount the reality of climate change but instead seek to problematize the framing of sinking Pacific Islands as a "lost paradise," which creates ideas of agency as foreign and locals as "victims." We conclude here by briefly looking into this idea, in the hope that it may provide a fruitful avenue for future scholarship.

In this collection, we explore how, to Western audiences, Pacific Islands represent "harmonious alternatives to modern worlds . . . refuges from society and self" (Connell 2003, 573). The geographical nature of islands as enclosed, distant, and remote allows for the creation of an imaginative space onto which "paradise" ideas can be transposed, in part because of 
their physical removal from Western industrial landscapes (Grove I995; McNamara and Gibson 2009; DeLoughrey 2013; Alexeyeff and Taylor 20I6). From early European explorations onward, Pacific islands have long been established as "the last 'unspoiled' locations on earth" (Deckard 20IO, I2). Increasingly, the loss of these Edenic locales is made visible in the numerous images of "sinking" Pacific islands. Alongside these visual images, the trope of "paradise lost" is regularly attached to discussions of climate change in the Pacific (see, eg, Leonard 2008; Brangham 20I 2; Mathiesen 2015; Bender 2016).

Pacific Islands, so long commodified as idyllic fantasy locations, are increasingly viewed through the lens of threats posed by climate change. This is not a story in which a single environment is devastated but rather one in which the loss of utopian islands heralds the destruction of the global environment by industrialized capitalism. Just as European fascination with Pacific places in the eighteenth and nineteenth centuries was premised on "tropical islands and colonies [that] became symbolic locations on which to project the contradictions of European expansion" (Deckard 20IO, IO), so too have Pacific Islands come, once again, to represent in material form the moral implication of rapacious industrial expansion that pays no heed to environmental consequences.

The impacts of climate change in the Pacific are real. One of the problems we have with the "paradise lost" discourse is that it portrays Pacific Islanders as passive victims of industrial expansion and as "ventriloquists" who represent a particular crisis in nature, in the process depriving Islanders of agency (Farbotko and Lazrus 2012, 385). A rejoinder to these ideas is the "We are not drowning. We are fighting" campaign initiated by 350 .org Pacific, which includes a series of powerful photographs of Pacific Islanders in warrior poses. These images of Pacific climate warriors are aimed at a global audience. The campaign material describes the motivation for producing these pictures: "There's a common perception that the Pacific Islands are drowning from sea-level rise. . . . it's time to change the global narrative of the Pacific Islands-from drowning and victimisation, to building the power to fight the fossil fuel industry, and climate change" (Packard 20I3).

The Pacific climate warrior campaign in Australia involved thirty Pacific Islanders-in customary dress and in canoes crafted in each of their representative islands-supported by hundreds of Australians as together they blocked the export of coal from Newcastle. In this campaign, Pacific Islanders are challenging the moral legitimacy of coal-producing coun- 
tries. These actions and images highlight the agency of climate warriors and stand in stark contrast to the imagery and discourses of a lost paradise that frame Pacific peoples within the "vanguard of victimhood" (Jolly 20I8; Scarr 2015). The campaign situates Pacific climate warriors as central, rather than marginal, in climate change processes and also foregrounds political action in Oceanic knowledge of climate; it is suggestive of a repossession of the narrative framing of climate change as it is applied to the Pacific and its peoples.

As well as exploring neocolonial possession of landscapes by foreigners, this collection considers how Pacific agents may also draw on the trope of paradise in order to counter contemporary dispossession. Here, paradise emerges as a complex combination of Indigenous epistemologies, Christian discourses, global images, and capitalist commoditization. In this way, paradise speaks to spiritual concerns, debates about sovereignty, land dispossession, global warming, and cultural integrity, as well as to moral diagnoses on the state, the self, and the soul. In this we are reminded of Tracey Banivanua Mar's last work, Decolonisation and the Pacific (2016), in which she traced how decolonization occurred through counter-imperial networks and the reappropriation of colonial discourses and strategies that were on the one hand "deeply destructive but on the other, they were facilitators of a cross-fertilisation of ideas and the articulation of resistant politics, cultures and languages" (2016, I7). In the present day, the technology of globalization is used to reframe colonial and postcolonial appropriations and includes music, art, social media, and film.

As scholars engaged in the broader process of analyzing paradise, completing this work has raised a series of hard questions for us. It has become clear that we need to hone our critical tools to more fully account for how Pacific and non-Pacific people are embedded in global capital-both to counter neocolonial systems of exploitation and to develop creative approaches to decolonize our thinking and practice from a range of locations. It is our hope that this special issue creates a productive dialogue between seemingly oppositional perspectives on ownership, appropriation, resistance, and agency.

Across Pacific communities, string bands croon songs about their home islands as paradise and narratives of Pacific paradise are mobilized by local inhabitants in a range of ways: as a yearning for home experienced by diasporic populations, as critical and deeply politicized in artistic practice, as Christian interpretations of disaster as divine judgment, or in Indigenous Hawaiian notions of harmony between people and the natural world. In 
each of these accounts, the use of paradise expresses connections of Pacific peoples to a revered, idyllic place, and also serves to frame economic, political, and spiritual projects that arise from specific places. These narratives, songs, sermons, and activism function as a rejoinder to the idea that Pacific paradise serves only as a playground for foreigners. In the midst of this traffic between imaginaries and materialities both Indigenous and foreign, it is clear that the concept of paradise holds an enduring significance in the contemporary Pacific.

We would like to ACKNowledge Alexander Mawyer for his support of this volume and also his helpful editorial guidance. Our warm thanks to Margaret Jolly, Mārata Tamaira, and the anonymous reviewers who provided us with much useful advice on the collection as a whole and this introduction in particular. Benedicta Roussean and Geraldine Fela also assisted us enormously with the preparation of the manuscript; many thanks. A final thanks to The Contemporary Pacific editorial team and in particular Jan Rensel and Zakea Boeger for their thoughtful editing suggestions.

\section{Note}

I See http://yourparadise.com/, https://www.instagram.com/yourparadisefiji/, and https://www.facebook.com/YourParadiseFiji/ [accessed I 3 March 20I8].

\section{References}

Alexeyeff, Kalissa

2008 Are You Being Served? Sex, Humour and Globalisation in the Cook Islands. Anthropological Forum I 8 (3): 287-293.

2016 Re-purposing Paradise: Tourism, Image and Affect. In Touring Pacific Cultures, edited by Kalissa Alexeyeff and John Taylor, 403422. Acton, ACT: ANU Press.

Alexeyeff, Kalissa and John Taylor, editors 2016 Touring Pacific Cultures. Acton, ACT: ANU Press.

Amherst, William Amhurst Tyssen-Amherst, Baron, Gomez Hernandez Catoira, Alvaro Mendaña de Niera, Pedro Sarmiento de Gamboa, Hernan Gallegos Lamero, and Basil Thomson

I967 The Discovery of the Solomon Islands by Alvaro De Mendaña in I 568, 2 volumes. Translated from the original Spanish manuscripts 
and edited with introduction and notes, by Lord Amherst of Hackney and Basil Thomson. Nendeln, Liechtenstein: Kraus Reprint. First published in I90I by the Kahluyt Society, London.

Appadurai, Arjun

I986 Introduction: Commodities and the Politics of Value. In The Social Life of Things: Commodities in Cultural Perspective, edited by Arjun Appadurai, 3-63. Cambridge, uK: Cambridge University Press.

Ballard, Chris

2013 "It's the Land, Stupid!" The Moral Economy of Resource Ownership in Papua New Guinea. In The Governance of Common Property in the Pacific Region, edited by Peter Larmour, 47-65. Acton, ACT: ANU Press.

Bender, Lyn

2016 The Boat People from Paradise Lost. Eureka Street [a daily online publication of the Australian Jesuit Province], 22 April. https:// www.eurekastreet.com.au/article.aspx?aeid $=47240$ [accessed 20 Feb 20I 8]

Besnier, Niko, and Kalissa Alexeyeff, editors

2OI4 Gender on the Edge: Transgender, Gay, and Other Pacific Islanders. Honolulu: University of Hawai'i Press.

Bougainville, Louis-Antoine

I772 A Voyage Round the World: Performed by Order of His Most Christian Majesty, in the Years I766, I767, I768, and I769 by Lewis de Bougainville. Translated by John Reinhold Forster. London: Nourse and Davies.

Brangham, William

2012 Paradise Lost in Palau: Island Nation Fights Back Against Climate Change. Grist, 22 Aug. http://grist.org/climate-energy/paradise-lost -in-palau-island-nation-fights-back-against-climate-change [accessed I 2 Oct 2016]

Calder, Alex, Jonathan Lamb, and Bridget Orr, editors

I999 Voyages and Beaches: Pacific Encounters, I769-1840. Honolulu: University of Hawai'i Press.

Connell, John

2003 Island Dreaming: The Contemplation of Polynesian Paradise. Journal of Historical Geography 29 (4): 554-58I.

2006 "The Taste of Paradise": Selling Fiji and Fiji Water. Asia Pacific Viewpoint $47(3): 342-350$.

Deckard, Sharae

2010 Paradise Discourse, Imperialism, and Globalization: Exploiting Eden. London: Routledge. 
DeLoughrey, Elizabeth M

20I3 The Myth of Isolates: Ecosystem Ecologies in the Nuclear Pacific. Cultural Geographies 20 (2): I 67-I 84

Dening, Greg

I992 Mr Bligh's Bad Language: Passion, Power and Theatre on the Bounty. Cambridge, uk: Cambridge University Press.

I996 Performances. Carlton, vic: Melbourne University Publishing.

2004 Beach Crossings: Voyaging Across Times, Cultures, and Self. Carl-

Desmond, Jane C ton, vic: Melbourne University Publishing.

I999 Staging Tourism: Bodies on Display from Waikiki to Sea World. Chicago: University of Chicago Press.

Diaz, Vicente

2016 Disney Craps a Cute Grass Skirt: Unpacking Insidious Colonial Power and Indigenous Enabling in Disney's "Moana." The Hawaii Independent, 29 Sept. http://hawaiiindependent.net/story/disney -craps-cute-grass-skirt [accessed 20 Sept 2017]

Eisenman, Stephen F

I997 Gauguin's Skirt. London: Thames and Hudson.

Enloe, Cynthia

I989 Bananas, Beaches and Bases: Making Feminist Sense of International Politics. London: Pandora.

Farbotko, Carol, and Heather Lazrus

2012 The First Climate Refugees? Contesting Global Narratives of Climate Change in Tuvalu. Global Environmental Change 22 (2):382-390.

Filer, Colin, Siobhan McDonnell, and Matthew Allen 2017 Powers of Exclusion in Melanesia. In Kastom, Property and Ideology: Land Transformations in Melanesia, edited by Siobhan McDonnell, Matthew Allen, and Colin Filer, I-55. Acton, ACT: ANU Press.

Foster, Robert J

2008 Coca-Globalization: Following Soft Drinks from New York to New Guinea. New York: Palgrave MacMillan.

Fresno-Calleja, Paloma

2013 Revised Spectacles: Literary Transformations of Hollywood's Pacific Narratives. Journal of Postcolonial Writing 49 (3): 265-277.

Gonzalez, Vernadette V

2010 Touring Military Masculinities: US-Philippines Circuits of Sacrifice and Gratitude in Corregidor and Bataan. In Militarized Currents: Toward a Decolonized Future in Asia and the Pacific, edited by Setsu Shigematsu and Keith L Camacho, 63-88. Minneapolis: University of Minnesota Press. 
Grimshaw, Patricia

I989 Paths of Duty: American Missionary Wives in Nineteenth-Century Hawaii. Honolulu: University of Hawai'i Press.

Grove, Richard H

I995 Green Imperialism: Colonial Expansion, Tropical Island Edens and the Origins of Environmentalism, I600-1860. Cambridge, UK: Cambridge University Press.

Hall, C Michael

I998 Making the Pacific: Globalization, Modernity and Myth. In Destinations: Cultural Landscapes of Tourism, edited by Greg Ringer, I 40-I 53. London: Routledge.

Hermann, Elfriede, editor

20I I Changing Contexts, Shifting Meanings: Transformations of Cultural Traditions in Oceania. Honolulu: University of Hawai'i Press.

hooks, bell

I992 Black Looks: Race and Representation. Boston: South End Press.

Huffer, Elise, editor

2008 Land and Women: The Matrilineal Factor; The Cases of the Republic of the Marshall Islands, Solomon Islands and Vanuatu. Suva: Pacific Islands Forum Secretariat.

Hviding, Edvard

2004 Contested Rainforests, NGOs, and Projects of Desire in Solomon Islands. International Social Science Journal 55 (I78): 539-554.

Iron Lion

2016 Beyond Disney's Moana: In the Spirit of Maui. Video, I 5 minutes, posted $28 \mathrm{July}$. https://www.youtube.com/watch?v=OdsRO 4 i7pFM [accessed 7 Aug 2017]

Jolly, Margaret

I992 "Ill-Natured Comparisons"? Racism and Relativism in European Representations of ni-Vanuatu from Cook's Second Voyage. In Colonialism and Culture, edited by Nicholas Thomas. Special issue of History and Anthropology 5 (3-4): 33 I-364.

I997a From Point Venus to Bali Ha'i: Eroticism and Exoticism in Representations of the Pacific. In Sites of Desire, Economies of Pleasure: Sexualities in Asia and the Pacific, edited by Lenore Manderson and Margaret Jolly, 99-I22. Chicago: University of Chicago Press.

I997b White Shadows in the Darkness: Representations of Polynesian Women in Early Cinema. Pacific Studies 20 (4): I 25 -I 50.

2007 Imagining Oceania: Indigenous and Foreign Representations of a Sea of Islands. The Contemporary Pacific I9 (2): 508-545. 
2009 The Sediment of Voyages: Re-membering Quiros, Bougainville and Cook in Vanuatu. In Oceanic Encounters: Exchange, Desire, Violence, edited by Margaret Jolly, Serge Tcherkézoff, and Darrell Tryon, 57-III. Acton, ACT: ANU Press.

2016 "When She Cries Oceans": Navigating Gender Violence in the Western Pacific. In Gender Violence and Human Rights: Seeking Justice in Fiji, Papua New Guinea and Vanuatu, edited by Aletta Biersack, Margaret Jolly, and Martha Macintyre, 34I-380. Acton, АCT: ANU Press.

2018 Horizons and Rifts in Conversations about Climate Change. In Pacific Futures: Past and Present, edited by Miranda Johnson, Warwick Anderson, and Barbara Brookes. Honolulu: University of Hawai'i Press, forthcoming.

Jolly, Margaret, Serge Tcherkézoff, and Darrell Tryon, editors

2009 Oceanic Encounters: Exchange, Desire, Violence. Acton, ACT: ANU Press.

Kahn, Miriam

2003 Tahiti: The Ripples of Myth on the Shores of the Imagination. History and Anthropology I4 (4): 307-326.

20II Tahiti Beyond the Postcard: Power, Place, and Everyday Life.

Kaplan, Martha Seattle: University of Washington Press.

20I I Alienation and Appropriation: Fijian Water and the Pacific Romance in Fiji and New York. In Changing Contexts, Shifting Meanings: Transformations of Cultural Traditions in Oceania, edited by Hermann Elfriede, 22 I-234. Honolulu: University of Hawai'i Press.

Kihara, Yuki

2005 Fa'afafine: In the Manner of a Woman. Solo photographic exhibition, Sherman Galleries, Sydney.

Landman, Jane

2006 The Tread of a White Man's Foot: Australian Pacific Colonialism and the Cinema, 1925-1962. Canberra, АСт: Pandanus Books.

Landman, Jane, and Chris Ballard

2010 An Ocean of Images. Journal of Pacific History 45 (I): I-20.

Larmour, Peter, editor

2013 The Governance of Common Property in the Pacific Region. Canberra, ACT: ANU Press.

Leonard, Abigail, producer

2008 Paradise Lost. PBs television, aired I 2 Dec.

LiPuma, Edward

I998 Modernity and Forms of Personhood in Melanesia. In Bodies and 
Persons: Comparative Perspectives from Africa and Melanesia, edited by Michael Lambeck and Andrew Strathern, 53-79. Cambridge, UK: Cambridge University Press.

MacCarthy, Michelle

2016 Making the Modern Primitive: Cultural Tourism in the Trobriand Islands. Honolulu: University of Hawai'i Press.

Mar, Tracey Banivanua

2016 Decolonisation and the Pacific: Indigenous Globalisation and the Ends of Empire. Cambridge, uk: Cambridge University Press.

Marx, Karl

I990 Capital: A Critique of Political Economy, Volume I. Translated by Ben Fowkes. Reprint, London: Penguin Classics. Originally published in $\mathrm{I} 867$.

Mathiesen, Karl

20 I 5 Losing Paradise: The People Displaced by Atomic Bombs, and Now Climate Change. The Guardian, 9 March. https://www.theguardian .com/environment $/ 20$ I $5 / \mathrm{mar} / 09 /$ losing-paradise-the-people -displaced-by-atomic-bombs-and-now-climate-change [accessed I2 Oct 2017]

Matsuda, Matt K

$20 \mathrm{I} 2$ Pacific Worlds: A History of Seas, Peoples, and Cultures. Cambridge, uk: Cambridge University Press.

Mawyer, Alexander

I998 From Photons to Electrons: The Film Guide, Moving Images of the Pacific Islands. The Contemporary Pacific Io (2): 457-465.

McDonnell, Siobhan

2016 My Land, My Life: Power, Performance and Identity in Land Transformations in Vanuatu. PhD dissertation, the Australian National University.

McNamara, Karen, and Chris Gibson

2009 "We Do Not Want to Leave Our Land": Pacific Ambassadors at the United Nations Resist the Category of "Climate Refugees." Geoforum $40(3): 475-483$.

Mintz, Sidney

I985 Sweetness and Power: The Place of Sugar in Modern History. New York: Viking Press.

Nelson, Hank

1992 "Write History: Reel History." In Pacific Islands History: Journeys and Transformations, edited by Brij V Lal, I84-202. Acton, ACT: ANU Press. 
Newell, Jennifer

2006 Collecting from the Collectors: Pacific Islanders and the Spoils of Europe. In Cook's Pacific Encounters: The Cook-Forster Collection of the Georg-August University of Göttingen, 29-47. Exhibition catalogue. Canberra: National Museum of Australia.

Ngata, Tina

2016 Maui “Skin Suit" Isn't the End of "Moana” Trouble. Honolulu Civil Beat, 27 Sept. http://www.civilbeat.org/2016/og/maui-skin-suit-isnt -the-end-of-moana-trouble/ [accessed I 2 Sept 20I7]

O'Brien, Patty

2006 The Pacific Muse: Exotic Femininity and the Colonial Pacific. Seattle: University of Washington Press.

O'Dwyer, Carol

I995 American Identity across the Pacific: Culture, Race, and Sexuality in

Packard, Aaron South Pacific and Tales from the South. Antithesis 7 (2): I $23-\mathrm{I} 37$.

2013350 Pacific: We Are Not Drowning. We Are Fighting. 350.org, I 7 Feb. https://350.org/350-pacific-we-are-not-drowning-we-are-fighting/ [accessed I 5 Sept 2017]

Sahlins, Marshall

2008 The Western Illusion of Human Nature: With Reflections on the Long History of Hierarchy, Equality and the Sublimation of Anarchy in the West, and Comparative Notes on Other Conceptions of

Said, Edward the Human Condition. Chicago: Prickly Paradigm.

I993 Culture and Imperialism. New York: Alfred A Knopf.

Salmond, Anne

I99I Two Worlds: First Meetings between Maori and Europeans I642I772. Auckland: Viking.

I998 Between Worlds: Early Exchanges between Maori and Europeans I773-I8I5. Auckland: Viking.

2003 The Trial of the Cannibal Dog: Captain Cook the South Seas. London: Allen Lane, Penguin Books.

Scarr, Miranda

20I5 The Gendered Discourse of Climate Change: Oceanic Counter Frames. BA honours thesis, the Australian National University.

Scheurmann, Erich

2007 Tuiavii's Way: A South Sea Chief's Comments on Western Society. Adapted and translated into English by Peter C Calveti. Revised and updated edition. Toronto: Legacy Editions. First published as Der 
Papalagi die Reden des Südseehäuptlings Tuiavii aus Tiavea. BuchenSmith, Bernard bach: Felsenverlag (1920).

I985 European Vision and the South Pacific. Second edition. New Haven, Ст: Yale University Press. Originally published in I960.

Strachan, Ian Gregory

2002 Paradise and Plantation: Tourism and Culture in the Anglophone Caribbean. Charlottesville: University of Virginia Press.

Strathern, Marilyn

I988 The Gender of the Gift: Problems with Women and Problems with Society in Melanesia. Berkeley: University of California Press.

Sykes, Karen

2007 Interrogating Individuals: The Theory of Possessive Individualism in the Western Pacific. Anthropological Forum I7 (3): 213-224.

Tamaira, A Mārata

2010 From Full Dusk to Full Tusk: Reimagining the "Dusky Maiden" through the Visual Arts. The Contemporary Pacific 22 (I): I-35.

2016 Native Realities in an Imaginary World: Contemporary Kanaka Maoli Art at Aulani, A Disney Resort and Spa. In Touring Pacific Cultures, edited by Kalissa Alexeyeff and John Taylor, I67-I8I. Acton, ACT: ANU Press.

Taouma, Lisa

2004 "Gauguin is Dead ... There is No Paradise." Journal of Intercultural Studies 25 (I): 35-46.

Taylor, John

$200 \mathrm{I}$ Authenticity and Sincerity in Tourism. Annals of Tourism Research 28 (I): 7-26.

2017 Pikinini in Paradise: Photography, Souvenirs and the "Child Native" in Tourism. In Touring Pacific Cultures, edited by Kalissa Alexeyeff and John Taylor, 36I-378. Acton, ACT: ANU Press.

Tcherkézoff, Serge

2004 "First Contacts" in Polynesia: The Samoan Case (I722-I 848); Western Misunderstandings about Sexuality and Divinity. Canberra, АCT: Journal of Pacific History Monographs; Christchurch, NZ: Macmillan Brown Centre for Pacific Studies.

2009 A Reconsideration of the Role of Polynesian Women in Early Encounters with Europeans: Supplement to Marshall Sahlins' Voyage around the Islands of History. In Oceanic Encounters: Exchange, Desire, Violence, edited by Margaret Jolly, Serge Tcherkézoff, and Darrell Tryon, II3-I60. Acton, ACT: ANU Press. 
Teaiwa, Katerina M

2014 Consuming Oceania: Stories of People and Phosphate from Banaba. Bloomington: Indiana University Press.

Teaiwa, Teresia

I994 bikinis and other s/pacific n/oceans. The Contemporary Pacific 6 (I): 87-I09.

I999 Reading Paul Gauguin's Noa Noa with Epeli Hau'ofa's Kisses in the Nederends: Militourism, Feminism, and the "Polynesian" Body. In Inside Out: Literature, Cultural Politics, and Identity in the New Pacific, edited by Vilsoni Hereniko and Rob Wilson, 249-263. Boston: Rowman \& Littlefield.

2016 Teresia Teaiwa: I Was Once Seduced by Disney. But No Longer. E-Tangata, 9 Oct. https://e-tangata.co.nz/news/teresia-teaiwa-i-was -once-seduced-by-disney [accessed 25 Aug 20I7]

Thomas, Nicholas

I99I Entangled Objects: Exchange, Material Culture, and Colonialism in the Pacific. Cambridge, ma: Harvard University Press.

2003 Discoveries: The Voyages of Captain Cook. London: Allen Lane.

2010 Islanders: The Pacific in the Age of Empire. New Haven, ст: Yale University Press.

Tomlinson, Matt

2002 In God's Image: The Metaculture of Fijian Christianity. Berkeley: University of California Press.

Trask, Haunani-Kay

I993 From a Native Daughter: Colonialism and Sovereignty in Hawai'i. Monroe, ME: Common Courage Press.

Wallace, Lee

2003 Sexual Encounters: Pacific Texts, Modern Sexualities. New York: Cornell University Press.

\section{Abstract}

This essay is a critical reexamination of the trope of paradise. This trope has a long global history encompassing colonial imaginings and missionary and travel narratives, and notions of "paradise" continue to influence contemporary narratives of place and landscape in the Pacific for Indigenous groups and others. While much has been written about the potency of the paradise trope in the West, it is often implicitly assumed that Indigenous engagement with the trope amounts to a simple rejection or dismissal of "paradise." In contrast, we suggest that the 
dynamics of possession, dispossession, and repossession of paradise require further investigation. Paradise is both an imaginary that frames foreign engagement with the Pacific and a complex political landscape that is mobilized by Indigenous people both to contest neocolonial forms of appropriation and exploitation and to affirm local articulations of ownership and belonging in the Pacific.

KEYWORDS: paradise, possession, colonialism, tourism, globalization, Pacific representation, identity politics 